\title{
Epidemic of Legionella Pneumophila Pneumonia South of Brescia (Italy)
}

\section{Sergio Perini}

ATS Health Protection Agengy of Brescia, Basic Medicin Sevice, ISDE (International Society of Doctors for the Environment), Brescia, Italy

\section{Email address:}

info@sergioperini.it

\section{To cite this article:}

Sergio Perini. Epidemic of Legionella Pneumophila Pneumonia South of Brescia (Italy). International Journal of Infectious Diseases and Therapy. Vol. 6, No. 2, 2021, pp. 61-64. doi: 10.11648/j.ijidt.20210602.13

Received: April 8, 2021; Accepted: May 5, 2021; Published: May 14, 2021

\begin{abstract}
In September 2018, a serious epidemic of Legionella Pneumophila serotypes 1-2-14, diagnosed by the Istituto Superiore Sanità (ISS), occurred in the low plain south of Brescia. This resulted in a considerable number of hospitalizations in the hospitals of the ATS of Brescia and Valpadana (Mantua) with high mortality rate. It was an anomalous situation both for the spread and for the Legionella serotypes which alarmed the Istituto Superiore Sanità and the local health structures. This epidemic is an expressions of the malaise of the geographical area in question caused by the impact of various environmental degradations. Some environmental criticalities: 1-the low water flow of the Chiese river in the summer of 2018 due to the exploitation of water by intensive agriculture and the presence of 22 hydroelectric power plants along its course. 2-the presence of numerous industrial cooling towers with a lack of mapping of the same towers by the political bodies (Region and Municipalities). 3-the abnormal disposal of sludge on the countryside surrounding the agricultural area adjacent to the river bed of the Chiese river as a consequence of the enormous production of livestock waste by pig, cattle and chicken farms in the same area. 4-In the lower Brescia plain there are numerous disposal companies that receive sewage sludge from 15 regions of Italy and also from abroad. 5-different and numerous types of landfills in the municipalities of Montichiari, Rezzato, Ghedi, Calcinato and Bedizzole filled with 12 million cubic meters of toxic-harmful waste. 6- the Lombardy region allows an excessive number of CERs (Catalog European Waste). It concludes by emphasizing how everyone, citizens and institutions, have a great responsibility in the management of the territory and a change of direction is hoped for an economy that has reached limits that it can no longer tolerate. This calls the various responsibilities of Politics, Public Health, the industrial and agricultural world in the management of a territory that continues to send signs of suffering and which is reflected on the health of men, animals and the plant world.
\end{abstract}

Keywords: Legionella Pneumophila, Pneumonia Epidemic, Brescia (Italy)

\section{Introduction}

At the beginning of September 2018, a serious epidemic of Legionella pneumophia occurred in the lower Po valley, south of Brescia, involving in particular 7 municipalities (Montichiari, Carpenedolo, Visano, Remedello, Acquafredda, Isorella, Calvisano) comprising nearly 60,000 inhabitants.

Legionella pneumophila is a bacteria that colonizes natural and artificial aquatic environments, in particular the peripheral systems of hot water distributions between $25^{\circ} \mathrm{C}$ and $45^{\circ} \mathrm{C}$ in hospitals, spas and tourist accommodation facilities.

In September, in the area of competence of ATS Brescia and Valpadana, 878 cases of community acquired pneumonia were reported, of which 64 were identified as legionellosis serotype 1 with research of urinary antigens and blood antibodies (IgM and IgG).

A community epidemic caused by Legionella pneumophila serogroups other than type 1 has so far never been described in the analysis of the scientific literature [1-3].

In Italy, clusters of legionellosis have occurred in the hospital setting caued by serogroup 6 and others have been described in the literature caused by other serogroups but always in a nosocomial setting. [1]

\section{Materials and Methods}

As a general practitioner, I work in Carpenedolo, one of the 7 municipalities of the lower Brescia area involved in this pandemic of pneumonia which took place in September 2018. 
I dealt with this health emergency by carefully following both the health events of my patients ( 15 cases of pneumonia on 1600 patients) and the various phases of the health emergency in the whole area managed by the ATS Health Protection Agengy of Brescia.

Below, you will find a brief summery of the information and data provided at the time to the press and to general practitioners of the same ATS [5].

Thursday 6th September 2018: first reports of suspected pneumonia reported by the Hospital of Montichiari (about 50 in 3 days); start epidemiological investigations.

Friday 7th September: epidemiological investigations and establishment of a coordination group.

Saturday 8th September: 1st bulletin: 71 cases of pneumonia reported, 2 positive for legionella, 7 municipalities affected (Acquafredda, Visano, Remedello, Calvisano, Carpenedolo, Isorella and Montichiari); launch of environmental surveys, meetings with GPs, water network managers and Mayors of the municipalities involved; first communication to the population.

Monday 10th September: 2nd Bulletin: 158 cases of pneumonia of which 11 positive for Legionella; meeting with the ASSTs: daily access report of the ED with a diagnosis of pneumonia + hospitalized patients flow. Indication: search for Legionella and Pneumococcus in all pneumonia of unknown origin.

Friday 14th September: videoconference with the Lombardy Region, ISS (National Institute of Health), ATS Val Padana, ASST Mantova, ASST Spedali Civili and the University of Brescia. 3rd Bulletin: 360 pneumonia reported, of which 29 positive for Legionella for ATS Brescia and 4 for ATS Val Padana.

21st September and 19th October: videoconference with ISS, Lombardy Region, ASST Spedali Civili, University of Brescia, ASST Mantua, ATS Val Padana for updates and sharing of operating procedures.

31st October: 4th Bulletin: 878 cases of pneumonia reported, 64 total positivity for Legionella pneumophila 1 (7.2\%) (60 ATS Brescia and 4 ATS Val Padana) [4-6]

\section{Results}

Thanks to molecular biology tests with PCR (Polymerase Chain Reaction) performed by the ISS on $90 \%$ of both autopsy and environmental samples, we saw the presence of serotypes 1 but also of the rarer serotypes 2 and 14 of Legionella pneumophila. This was an anomalous finding considering that in Italy $90 \%$ of legionella pneumonia are due to serotype 1 .

The other anomaly of this epidemic, contrary to what happened in the past in Italy and in other parts of the world, is the involvement of not only a single structure but of a vast geographical area along the river Chiese with 34 positive cases out of 533 samples examined (table 2) in private homes, sports facilities, cooling towers of 3 companies - all along and in vicinity of the same Chiese river: 5 positivity of serotype 1, 24 positivity of serotypes 2 and 14: 5 cases of serotypes 1-2-14 [5]. Also in other areas of the territory of the ATS of Brescia searches were carried out for the presence of Legionella (Table 1) with 117 positivity on 1060 samples: 47 positivity of serotype 1,57 positivity of serotype 2 and 14 and 12 positivity of serotypes $1-2-14$. [4-6]

This epidemic of Legionella Pneumophila type 1-2-14 in the lower eastern Brescia area is considered by the ISS to be a unique event in the world.

Compared to the 878 cases of pneumonia diagnosed in the ED there were 655 hospitalizations with mean age of 63.5 years of which $39.6 \%$ less than 60 years old and $38.3 \%$ higher than 75 years old.

Another indicative element is the comparison of the incidence rate of pneumonia of the same ATS in 2017=51 / 100,000 and in $2018=66 / 100,000$ against the following-

incidence rates of the 7 municipalities involved for 2019:

Acquafredda: 1027 / 100,000

Visano: 672 / 100,000

Remedello: 637 / 100,000

Calvisano: 469 / 100,000

Carpenedolo: 423 / 100,000

Isorella: 345 / 100,000

Montichiari: 269 / 100,000

Table 1. ISS data of the entire ATS from 8/9 to 12/11/18 (6).

\begin{tabular}{|c|c|c|c|c|c|}
\hline Sampling site & no. Sample & legionella + & serotype 1 & serotype $2-14$ & $1+2+14$ \\
\hline Private residence & 449 & 31 & 7 & 24 & 0 \\
\hline Aqueduct & 101 & 0 & 0 & 0 & 0 \\
\hline Water well & 90 & 8 & 3 & 3 & 2 \\
\hline Cooling towers & 143 & 27 & 14 & 3 & 10 \\
\hline River Chiese & 14 & 7 & 0 & 7 & 0 \\
\hline Sport facilities & 263 & 44 & 23 & 20 & 0 \\
\hline Total & 1060 & 117 & 47 & 57 & 12 \\
\hline
\end{tabular}

Table 2. ISS data of the 7 Municipalities (Montichiari, Carpenedolo, Visano, Remedello, Acquafredda, Isorella, Calvisano) (6).

\begin{tabular}{lllll}
\hline Sampling site & no samples & + legionella & Serotype 1 & Serotype 2-14 \\
\hline Private residence & 262 & 12 & 2 & 10 \\
Aqueduct & 83 & 0 & 0 & 0 \\
water well & 54 & 2 & 0 & 0 \\
Cooling towers & 102 & 10 & 3 & 1 \\
River Chiese & 14 & 7 & 0 & 3 \\
Sports facilities & 18 & 3 & 0 & 7 \\
total & 533 & 34 & 5 & 3 \\
\hline
\end{tabular}


Table 3. Specific mortality rate (6).

\begin{tabular}{llll}
\hline ATS table & Rest ATS & 7 municipalities & \\
\hline Resident population & $1,101,809$ & 57,087 & $\mathrm{P}<0.0001$ \\
Total deaths of the cohort & 67 & 11 & $\mathrm{P}<0.0001$ \\
Specific mortality rate $x 100,000$ & 6.1 & 19.3 & \\
\hline
\end{tabular}

Table 3 shows that the mortality rate index of the 7 Municipalities of the area affected by the pneumonia epidemic has an important significance with a $\mathrm{P}<0.0001$, an indisputable sign of the danger to humans of this type of infection. [4-6]

\section{Conclusion}

Here are some environmental aspects and some observations about the clinical situation in question:

As regards the Chiese river, it is worth noting the low water flow in the summer of 2018 for the exploitation of the water both from the 22 hydroelectric plants present along its course, from Daone to Acquanegra comprising 24 municipalities for a total of 148,606 inhabitants, and due to the enormous withdrawal of water by farmers for spreading irrigation of agricultural land. It should be noted that on August $16^{\text {th }} 2018$ the Consorzio Bonifica del Chiese (Resolution 8/18) reported the criticality for the minimum vital flow of the river to the AIPO (Agenzia Interregionale Fiume Po) and to the prefecture of Brescia.[8-10, 14, 16, 17]

There is a total lack of mapping of the industrial cooling towers by local polities (Regions and Municipalities) and as far as their maintenance is concerned there are only guidelines in place issued by the Ministry of Health in 2015 but ther eare no legally binding protocols. This leaves much leeway for the management and periodic maintenance of the plants themselves. [13]

A further element of reflection remains the abnormal disposal of pig slurry on the countryside bordering the river bed. The Lombardy Region, in recognition of the immense production of manure from pig farms, cattle and chicken rearing, has issued in late 2018 a decision that limits the spreading of the sludge in 170 Lombard municipalities. However this has not been enough to block slurry spreading considered as soil improvement but which is nothing else than sludge transformed by sulfuric acid or calcium carbonate, rich in heavy metals and chemicals that affect agricultural land and future agricultural production. This is possible due to the lack of legal norms that regulate this kind of spreading. [8, 10, 14, 15, 17]

In addition, numerous disposal companies proliferate in the lower Brescia area sewage sludge from another 15 regions of Italy and also from abroad due to the very lucrative income generated by spreading 364,000 tons / year. It is pointed out that the lower Brescia area has an abnormal production of animals $(1,500,000$ pigs, 400,000 cattle, 40 million chickens and turkeys) whose waste is spread by farmers on agricultural land. [7-10, 14]

While I'm sure there are agricultural operators that respect the PUA (Agricola Utilization Plan), it remains highly likely that some breeders spill slurry repeatedly on the same grounds, not respecting the ratio of $170 \mathrm{~kg} /$ Nitrogen / ha / year causing consequently both an impoverishment of the land and of the wastewater in the canals which then flow into the river Chiese. [11]

Some municipal administrations, more attentive to the problem of slurry, even with a pending and unclear legislation, have issued very restrictive municipal regulations with respect to the spreading.

To all this are added numerous different types of landfills in the Municipalities of Montichiari, Rezzato, Ghedi, Calcinato and Bedizzole filled with 12 million cubic meters of toxic-noxious waste from all over Italy and abroad with hundreds of trucks handling these substances day and night. All authorized by the Region after the various EIA (Environmental Impact Assessment) and SEA (Strategic Environmental Assessment) but without consideration of the cumulative pressure index and without respecting the precautionary principle. $[7,8,12,14]$

This raises the question of the CER (Catalog of European Wastes) that each region adheres to by sanctioning the treatment of various types of waste. It is not clear why the Lombardy Region authorizes several hundred while other Italian regions authorize much fewer. It is evident that the greater the number of authorized substances, the greater the presence of industries that intend to exploit the waste business. The current Lombardy regional policy favours these activities and thereby attracts waste from every part of Italy and also abroad while it seems more logical that each region would manage slurry on its own territory. [7, 11, 12, 14]

From the findings it is clear that there are many parties involved and it seems evident that this calls for political actors, public health, the industrial and agricultural sector to change the management of an area that continues to send signs of its suffering reflected in the health of the people, animals and plants. The risk is that in the next few years the situation could worsen exponentially, irreversibly altering our common land whose management depends on the conscience of us. Everyone, citizens and institutions, have a great responsibility and a change of direction is needed for an economy that has overreached limits and created a situation that can no longer be tolerate. $[7,8,12,14]$

In the Province of Brescia, there are countless committees and associations, which for years have been raising cries of alarm, often unheard by the powers that be.

\section{References}

[1] Newsletter of the Higher Institute of Health. Vol 30-number 9 September 2017 Legionnaires' disease in Italy in 2016-pag 3-8. 
[2] New guidelines for the prevention and control of legionellosis (www.iss.it lbinaryliss4 $\backslash$ C_17_pubblicazioni_362.pdf).

[3] Correa AM, Ferreira JS, Borges V et al. Probable personto person transmission of Legionnaires' disease. N. Eng J. Med 2016; 37 (5): 497-8.

[4] Epidemic pneumonia event - epidemiological report. ATS of Brescia. UO Epidemiology Update 26 September 2018.

[5] Laboratory Brescia Legionella Pneumophila: what role in pneumonia epidemics? Proceedings of the Conference of $10 / 12 / 2018$.

[6] Epidemic pneumonia event. Epidemiological report. ATS of Brescia. UO Epidemiology, UO Environmental Medicine. UO Infectious diseases Update 6 March 2019.

[7] Perini S.: Legionella pneumonia epidimic south of Brescia. Il Cesalpino-september 2019, number 48.

[8] Perini S.: Le mie domande s questa epidemia di polmoniteGiornale di Brescia del 5/10/2018.

[9] Reboni C. Allarme fanghi, scatta il piano di emergenza. Bresciaoggi 9//2018.
[10] ISDE: Medici di famiglia e inquinamento ambientale. Passoni Editore 2020.

[11] Affronte M. (Grees/EFA) Interrogazione con richiesta scritta alla Commissione Parlamento Europeo. Bruxelles. Oggetto: Epidemia legionella bassa pianura bresciana.

[12] Perini S. Il parere di Sergio Perini sull'ambiente. Corriere dei Carpini aprile 2019 Numero 26.

[13] AIB (Associazione Industriali Bresciana) Linee guida per la prevenzione della legionella nelle torri di raffredamento$10 / 12 / 2018$.

[14] Perini S. Riflessioni di un medico della bassa bresciana. Ordine dei Medici Brescia 8/10/218.

[15] Perini S. Lettere al Direttore. Aracne Editore 2020-Roma-pagg $50 / 64$ e 206/210.

[16] Consorzio di bonifica Chiese. Delibera del Consiglio di Amministrazione del consorzio n. 8/18 del 16/8/2018.

[17] Istituto Superiore di Sanità Rapporto ISTISAN 14/21 Linee guida per la valutazione del rischio nella filiera delle acque destinata al consumo umano secondo il modello dei Water Safety Plan. 